To cite this article: Dr. Samuel N. Waweru* and Njeru Pamela Gacheri (2021). INFLUENCE OF CLASSROOM BEHAVIOUR MANAGEMENT PRACTICES ON STUDENTS' ACADEMIC ACHIEVEMENT IN PUBLIC SECONDARY SCHOOLS IN THARAKA NITHI COUNTY, KENYA, International Journal of Education and Social Science Research (IJESSR) 4 (5): 166-174

\title{
INFLUENCE OF CLASSROOM BEHAVIOUR MANAGEMENT PRACTICES ON STUDENTS' ACADEMIC ACHIEVEMENT IN PUBLIC SECONDARY SCHOOLS IN THARAKA NITHI COUNTY, KENYA
}

\author{
Dr. Samuel N. Waweru* and Njeru Pamela Gacheri \\ Associate Dean \\ School of Education, Kenyatta University \\ P.O. Box 43844-00100, Nairobi, Kenya \\ *Corresponding author
}

DOI: http://dx.doi.org/10.37500/IJESSR.2021.4512

\begin{abstract}
The study described here sought to determine the influence of classroom behaviour management practices on learners' academic achievements in public secondary school in Tharaka Nithi County, Kenya. The study employed the descriptive survey research design, and was conducted among 14 principals, 19 teachers and 315 students who were from 14 public secondary schools. Data for the study were collected using questionnaires for teachers and students and interview schedules for school principals. The study established that the most commonly employed strategies to manage classroom discipline were Suspension, requiring deviant students to stand outside the classroom during lessons, separating deviant learners in class, and employing different instructional methods. The study concludes that, although these strategies were found to be effective in controlling student behaviour in the short term, the long-term outcomes may be detrimental to students in terms of academic achievement and future behaviour. The study recommends that teachers be trained on positive classroom behaviour management strategies that do not lead to students losing instructional time.
\end{abstract}

KEYWORDS: Classroom behaviour management, Academic achievement, Secondary education

\section{INTRODUCTION}

The ability of teachers to organize classrooms and manage the behavior of their students is critical to achieving positive educational outcomes. Although sound behavior management does not guarantee effective instruction, it establishes the environmental context that makes good instruction possible (Oliver \& Reschly, 2007). The challenges related to classroom management have heavily contributed to teacher stress and burnout, overall teacher self-efficacy, teacher performance and student achievement in the classroom (Jepson \& Forrest, 2006). Classroom management has been defined broadly as any action a teacher takes to create an environment that supports and facilitates both academic and social-emotional learning (Evertson \& Weinstein, 2006). Procedures that structure the 
classroom environment, encourage appropriate behaviour, and reduce the occurrence of inappropriate behaviour are necessary for strong classroom management (Oliver, Wehby \& Reschly, 2011; Cox, 2019). Classroom management is seen as the process of enhancing the learning environment, physical interaction between teachers and students, student to student, parents and others. Effective classroom management stimulates and motivates children to learn, enhances control and supervision throughout the school to facilitate and encourage co-operation in teaching and learning activities in the classroom, and this in turn improves the quality of students performance (Wisetrinthong, Sirisuthi \& Weangsamoot, 2012).

School administrators report classroom management, and especially student behavior management, as their greatest concern regarding new and struggling teachers (Nixon, Packard \& Douvanis, 2010). Particularly in the middle school years (ages 12-14), classroom management should balance the needs of teachers and their adolescent learners, enabling students to take personal responsibilities that lead to self-discipline and improved well-being (Chafouleas, Hagermoser, Jaffery \& Fallon, 2012). There is general consensus in the literature that students who experience recognition for responsible behaviour become more responsible, less distracted, and more positive toward teachers and schoolwork. On the other hand, teacher aggression, manifested in group punishment, humiliating students, and yelling in anger, appears to be associated with more student misbehavior and higher levels of negative student attitudes toward learning (Romi, Lewis \& Katz, 2009).

Student discipline is an area that needs to be taken care of within the classroom. According to DiBara, (2007), successful teaching requires more than controlling student behavior. According to Marzano and Marzano (2003) effective teaching and learning cannot take place in a poorly managed classroom. Emmer and Stough (2001) argued that the ability of teachers to organize classrooms and manage the behavior of their students is critical to achieving positive educational outcomes. Pederson-Seelye (2011) argued that effective classroom management procedures promote independent learning and success for all students in classrooms which are productive, orderly and pleasant.

In Kenya, despite the recent trends of teacher education programs to increase training in the area of classroom management and of school to correct teachers' deficiencies in classroom management skills, teachers continue to struggle with the reality of classroom discipline management issues. Of more concern is the fact that both novice and experienced teachers still struggle in raising learners' grades in public secondary schools (Ngando, 2011; Nzoka \& Orodho, 2014). The goal of this study was to establish the influence of classroom behaviour management practices on students' academic achievement in public secondary schools of Tharaka Nithi County, Kenya.

\section{Purpose of the Study}

The purpose of this study was to determine the influence of classroom behavior management practices on learners' academic achievements in public secondary school in Tharaka Nithi County, Kenya. 


\section{Objectives of the Study}

The objectives of the study were:

1. To establish the classroom behavior management practices of secondary school teachers in Tharaka Nithi County, Kenya.

2. To determine the influence of classroom behavior management practices on students' academic achievement.

\section{Literature Review}

Classroom behavior management refers to the strategies used by teachers to establish discipline and mutual respect in the classroom. The term "discipline" comes from the Latin word "discipulus", which means meaning pupil, learner, or disciple. The term has the essence of control in it and means "to teach someone to obey rules and control their behaviour or to punish someone in order to keep order and control" (Longman Dictionary of Contemporary English, 2005); and thus, it is mostly connoted with punishment in case of disobedience. Punitive behaviour management strategies such as detention are used in schools based on the premise that isolation gives the perpetrator time to reflect on what happened, realize the error of his or her ways, and return to the same situation but with a change of behaviour and attitude (Pane, 2010). Dillala and Mullineax (2008), in their study, found that there is a relationship between positive classroom climate and the social behavior of learners, viz., reduced bullying and conflict, together with greater cooperation and achievement.

In a pioneering empirical study investigating on classroom discipline, Lewis (2001) examined the role of classroom discipline in promoting student responsibility for learning in the classroom in Australia. The results showed that teachers' coercive discipline is perceived by students to be one key factor that inhibits the development of responsibility in students and distracts them from their schoolwork. In another study, Lewis et al. (2005) did a cross-cultural comparison of discipline methodologies teachers of different nationalities use. They reported that Chinese teachers use less punitive methodologies in their classes in comparison to their Australian colleagues as Chinese students normally listen to their teachers and misbehavior does not happen very often in their classes. In a follow up study, Lewis et al. (2008) investigated the extent to which students of different nationalities perceive their teachers' discipline methodologies to be key players in forming their attitudes towards the teacher and schoolwork. Regardless of their nationality, all students perceived punitive discipline methodologies to be related to distraction from schoolwork and shaping their feelings of resentment towards their teachers. The use of recognition of responsible behaviour method and discussing it with the students were also found to be related to less distraction of schoolwork.

Nie and Lao (2009) examined how two classroom management practices, care and behavioral control, were related to students' engagement, misbehavior, and satisfaction with school in Singapore. Results of the study showed that both care and behavioral control were positively related to student engagement. Behavioral control was found to be a hindrance to classroom misbehavior while care was a facilitator of students' satisfaction with school. In Africa, Elbla (2012) investigated the issue of 
corporal and verbal punishment as means of disciplining students' behaviour in schools of Sudan. The findings revealed that teachers use punitive methodologies as a result of the stress and frustration they themselves experience at school due to the fact that the school environment is poor and lacking facilities. This study however, did not relate discipline measures and learners' academic achievement. Though the reviewed studies acknowledge that classroom discipline is a significant factor influencing academic achievement of learners, they fail to show which classroom behaviour management practices yield positive results and which ones yield negative performance among students. The current study therefore sought to assess specific classroom behaviour management strategies and how they influence learners' academic achievement in public secondary schools.

\section{MATERIALS AND METHODS}

\section{Research design}

This study employed the descriptive survey research design. Descriptive research can be explained as a statement of affairs as they are at present with the researcher having no control over the study variables. Descriptive studies are simply the attempt to determine, describe or identify what is, without making any attempt to establish why it is that way or how it came to be (Ethridge, 2004).

\section{Study location and population}

The study was conducted in public secondary schools in Meru South sub-County of Tharaka Nithi County, Kenya. The target population for the study was 55 principals, 102 teachers and 3,150 students from 55 public secondary schools in Meru South sub-County, Tharaka Nithi County.

\section{Sample size and sampling technique}

From the target population of 55 public secondary schools, the researcher used stratified random sampling to select 14 schools for the study. From these 14 public secondary schools, purposive sampling was used to select all the 14 principals. Stratified random sampling was then used to select 19 teachers and 315 students from the 14 schools.

\section{Data collection and analysis}

Two types of instruments were used to collect data for this study: questionnaires and interview schedules. Two questionnaires were designed to collect data from teachers and students. The questionnaires were used to collect both qualitative and quantitative data as they had both open ended and closed ended questions. On the other hand, an interview schedule was designed to guide face-toface interviews with the principals. Descriptive statistics were used to analyze quantitative data obtained through students' and teachers' questionnaires. Content analysis was used to analyze the qualitative data collected through interview guide.

\section{RESULTS AND DISCUSSION}

\section{Classroom behavior management practices}


The first objective of this study was to establish the classroom behavior management practices of secondary school teachers in Tharaka Nithi County, Kenya. Teachers were asked to indicate the methods they commonly employed to manage classroom discipline. Their responses, as shown in Table 1, indicated that $15.8 \%$ of the teacher's employed suspension from school as a form of classroom discipline management. Teachers revealed further that this method was employed on notorious students who never listened to counsel from teachers. Teachers never used corporal punishment (caning) as a form of classroom behaviour management. This is as a result of the current Ministry of Education guidelines that outlaw corporal punishment in schools. Interviews with the principals revealed that this guideline makes students oftentimes misbehave in the classroom as there are no serious punishments that can affect them physically. It was revealed that students feared caning and always colluded with parents to intimidate teachers who made any attempts to use corporal punishment. According to DiBara (2007), successful teaching requires more than controlling students' behaviour. Teachers who preferred making students stand outside or separated deviant learners in class were $5.3 \%$ each while $73.7 \%$ of the teachers employed different instructional methods in managing classroom discipline. Effective teaching and learning cannot take place in a poorly managed classroom (Marzano \& Marzano, 2003).

Table 1: Classroom behaviour Management Practices

\begin{tabular}{lcccc}
\hline $\begin{array}{l}\text { Behaviour } \\
\text { management } \\
\text { practices }\end{array}$ & \multicolumn{2}{c}{ Teachers $(\mathbf{n}=\mathbf{1 9})$} & \multicolumn{2}{c}{ Students $(\mathbf{n}=\mathbf{3 1 5})$} \\
\cline { 2 - 5 } & $\begin{array}{c}\text { No. of } \\
\text { teachers }\end{array}$ & Percentage & $\begin{array}{c}\text { No. of } \\
\text { students }\end{array}$ & Percentage \\
\hline Suspension & 3 & 15.8 & 105 & 33.3 \\
Caning & 0 & 0.0 & 67 & 21.3 \\
$\begin{array}{l}\text { Standing outside } \\
\text { during lessons }\end{array}$ & 1 & 5.3 & 59 & 18.7 \\
$\begin{array}{l}\text { Separating deviant } \\
\text { learners in class }\end{array}$ & 1 & & & \\
Employing different & 11 & 5.3 & 13 & 4.1 \\
instructional methods & & 73.7 & & \\
\hline
\end{tabular}

Table 1 also shows that majority of the students revealed that teachers commonly used suspension and caning as the methods of instilling discipline in learners with a percent of $33.3 \%$ and $21.3 \%$ respectively. Another classroom discipline management method mentioned by the students included guidance and counseling, of which most of the students felt that the teachers did not provide confidentiality when it came to disclosing personal issues. 


\section{Influence of classroom behaviour management on academic achievement}

The second objective of the study was to determine the influence of classroom behaviour management practices on students' academic achievement. In order to establish the influence of classroom behaviour management practices on students' academic achievement, the teachers were presented with six Likert-type items that were measured on a 5-point scale - strongly agree (SA), agree (A), neutral $(\mathrm{N})$, disagree (D) and strongly disagree (SD). As shown in Table 2, majority of the teachers (78.4\%) strongly agreed or agreed that caning of learners greatly improves students' commitment in class which improves their academic achievement. The teachers were of the view that the introduction of the policy guidelines by the Ministry of Education banning corporal punishment impacted negatively on discipline of students. A smaller number of teachers were partly neutral, disagreed and strongly disagreed that caning can instill discipline and improve academic achievement. Majority of the teachers (52.6\%) disagreed that suspending deviant learners improves learners' academic achievement by eliminating sources of lesson distraction for other learners. The high number of teachers who disagreed may be as a result of feeling that suspending students wasted their time of study and made significant loopholes in creating bad relationships among teachers and students. However, 36.8\% of teachers strongly agreed and agreed that suspension could instill discipline.

Table 2: Influence of behaviour management practices on academic achievement

\begin{tabular}{|c|c|c|c|c|c|}
\hline Research Items & $\mathbf{S A}$ & $\mathbf{A}$ & $\mathbf{N}$ & $\mathbf{D}$ & SD \\
\hline $\begin{array}{l}\text { Caning of learners greatly } \\
\text { improves their commitment in } \\
\text { class which improves their } \\
\text { academic achievement }\end{array}$ & $\begin{array}{c}6 \\
(31.6 \%)\end{array}$ & $\begin{array}{c}7 \\
(36.8 \%)\end{array}$ & $\begin{array}{c}2 \\
(10.5 \%)\end{array}$ & $\begin{array}{c}2 \\
(10.5 \%)\end{array}$ & $\begin{array}{c}2 \\
(10.5 \%)\end{array}$ \\
\hline $\begin{array}{l}\text { Suspending deviant learners } \\
\text { improves learners academic } \\
\text { achievement by eliminating } \\
\text { sources of lesson distraction for } \\
\text { other learners }\end{array}$ & $\begin{array}{c}1 \\
(5.3 \%)\end{array}$ & $\begin{array}{c}6 \\
(31.6 \%)\end{array}$ & $\begin{array}{c}2 \\
(10.5 \%)\end{array}$ & $\begin{array}{c}8 \\
(42.1 \%)\end{array}$ & $\begin{array}{c}2 \\
(10.5 \%)\end{array}$ \\
\hline $\begin{array}{l}\text { Removing learners who interrupt } \\
\text { lesson and making them stand } \\
\text { outside the class improves silence } \\
\text { and learning which translates into } \\
\text { better academic achievement }\end{array}$ & $\begin{array}{c}5 \\
(26.3 \%)\end{array}$ & $\begin{array}{c}3 \\
(15.8 \%)\end{array}$ & $\begin{array}{c}1 \\
(5.3 \%)\end{array}$ & $\begin{array}{c}7 \\
(36.8 \%)\end{array}$ & $\begin{array}{c}3 \\
(15.8 \%)\end{array}$ \\
\hline $\begin{array}{l}\text { Ensuring that deviant learners do } \\
\text { not sit in the same place in class } \\
\text { eliminates avenues of } \\
\text { interruption, improving their }\end{array}$ & $\begin{array}{c}12 \\
(63.2 \%)\end{array}$ & $\begin{array}{c}3 \\
(15.8 \%)\end{array}$ & $\begin{array}{c}0 \\
(0.0 \%)\end{array}$ & $\begin{array}{c}1 \\
(5.26 \%)\end{array}$ & $\begin{array}{c}3 \\
(15.8 \%)\end{array}$ \\
\hline
\end{tabular}


concentration and participation

during lessons hence improving

their achievement

Using different instructional methods during lessons assists in enhancing learning and academic achievement of learners

14

$(73.7 \%)$

Appointing a prefect helps in controlling deviant behaviours in case of teacher's absence increases notes revision among learners which eventually 13 $(68.4 \%)$ 5 $(26.3 \%)$
4 $(21.1 \%)$ $(5.3 \%)$ 0 $(0.0 \%)$ $(0.0 \%)$ improves their academic achievement

On removing learners who interrupt a lesson and making them stand outside the class to instill discipline, there were $42.1 \%$ teachers who strongly agree and agree, while $52.6 \%$ of the teachers strongly disagreed and disagreed. On ensuring that deviant learners do not sit in the same place in class to instill discipline, $79 \%$ of the teachers strongly agreed and agreed, while $21.1 \%$ disagreed. On using different instructional methods during lessons to assist in enhancing learning and academic achievement of learners revealed that, $94.7 \%$ strongly agreed and agreed, while $5.3 \%$ were neutral. On appointing a prefect to help in controlling deviant behaviour in case of teacher's absence revealed that, $94.7 \%$ of the teachers agreed, while $5.3 \%$ were neutral.

\section{CONCLUSION AND RECOMMENDATIONS}

This study aimed at investigating the influence of classroom behaviour management practices on students' academic achievement in public secondary schools in Tharaka Nithi County, Kenya. The study established that the classroom behaviour management strategies employed by teachers greatly improved students' commitment in class, which led to improved academic achievement. Suspending deviant learners improved learners' academic achievement by eliminating sources of lesson distraction. The study also established that removing learners who interrupted the lesson and making them stand outside the class improved silence and learning which translated into better academic achievement. Similarly, ensuring that deviant learners did not sit on the same place in class eliminated avenues of interruption, improving their concentration and participation during lessons hence improving their academic achievement. Based on the study findings, it is recommended that teachers be trained on positive classroom behaviour management strategies that do not lead to students losing 
instructional time. While strategies such as suspension and spending time outside the classroom may yield short term benefits, they have been found to be detrimental in the long run.

\section{REFERENCES}

Chafouleas, S.M., Hagermoser, S.L., Jaffery, R., \& Fallon, L.M. (2012). An evaluation of a class wide intervention package involving self-management and a group contingency on classroom behavior of middle school students. Journal of Behavioral Education.

Cox, J. (2019). Classroom management for an effective learning environment. Retrieved 16/04/2021 from: https://www.teachhub.com/classroom-management/2019/05/classroom-managementfor-an-effective-learning-environment/

Dibara, J. (2007). Responsible to the kids: The goals and struggles of urban high school teachers. The New Educator.

DiLalla L.F., \& Mullineaux P.Y. (2008). The effect of classroom environment on problem behaviors: A twin study. Journal of School Psychology.

Elbla, A. I. F., (2012). Is punishment (corporal or verbal) an effective means of discipline in schools? Case study of two basic schools in Greater Khartoum/Sudan. Procedia - Social and Behavioral Sciences.

Emmer, E.T., \& Stough, L.M. (2001). Classroom management: A critical part of educational psychology, with implications for teacher education. Educational Psychologist.

Ethridge, D.E. (2004). Research methodology in applied economics. New Jersey: John Wiley \& Sons

Evertson, C. M., \& Weinstein, C. S. (2006). Handbook of classroom management, research, practice and contemporary issues. Mahwah, NJ: Erlbaum.

Jepson, E. \& Forrest, S. (2006). Individual contributory factors in teacher stress: The role of achievement striving and occupational commitment. British Journal of Educational Psychology.

Lewis, R., Romi, S., Katz, Y. J., \& Qui, X. (2008). Students' reaction to classroom discipline in Australia, Israel, and China. Teaching and Teacher Education,

Lewis, R., Romi, S., Qui, X., \& Katz, Y. J. (2005). Teachers' classroom discipline and student misbehavior in Australia, China, and Israel. Teaching and Teacher Education.

Longman Dictionary of Contemporary English (2005). UK: Pearson Longman. Iranian Journal of Language Teaching Research 3(1), (Jan., 2015) 
Marzano, R. J., Marzano, J. S., \& Pickering, D. J. (2003). Classroom management that works: Research-based strategies for every teacher. Alexandria, Virginia: Association for Supervision and Curriculum Development (ASCD).

Ngando N, N (2011) Time management behavior among secondary school personnel a case of Kinango District, Coast Province .Unpublished research project Kenyatta University.

Nie, Y., \& Lao, S. (2009). Complementary roles of care and behavioral control in classroom management: The self-determination theory perspective. Contemporary Educational Psychology, 34, 185-194.

Nixon, A., Packard, A., \& Douvanis, G. (2010). Non-renewal of probationary teachers: Negative retention. Education, 131(1), 43-53.

Nzoka, J.T., \& Orodho, J.A. (2014) School management and students academic performance: How effective are strategies being employed by school managers in secondary schools in Embu north district, Embu County Kenya? International Journal of Humanities and Social Sciences, 4(9),

Oliver, R.M., \& Reschly, D.J. (2007). Effective classroom management: Teacher preparation and professional development. Washington, DC: National Comprehensive Center for Teacher Quality.

Oliver, R.M., Wehby, J.H., \& Reschly, D.J. (2011). Teacher classroom management practices: effects on disruptive or aggressive student behavior. Campbell Systematic Reviews, 7(1), 1-55

Pane, D. (2010). Viewing classroom discipline as negotiable social interaction: A communities of practice perspective. Teaching and Teacher Education, 26, 87-97.

Pederson-Seelye, V.A. (2011). Effective classroom management procedures. Retrieved from file://F:/Newfolder(3)/284.short.htm.

Romi, S., Lewis, R., \& Katz, Y. (2009). Student responsibility and classroom discipline in Australia, China and Israel. Compare, 39(4), 439e452.

Wisethrinthong K., Sirisuthi C., \& Weangsamoot V. (2012). The development of classroom management system for the educational extension schools. European Journal of Social Sciences, 30(2), 313-320. 